\title{
Development of Price Forecasting Model for Common Timbers Available in Sri Lanka
}

\author{
A.L. Sandika \\ Department of Agricultural Economics and Extension, University of Ruhuna, Sri Lanka \\ sandika@agecon.ruh.ac.lk
}

\begin{abstract}
Timber is one of most valuable natural resources in the earth due to its use for a wide range of purposes. Demand for timber depends on many factors such as price, availability, durability and other gross features. However, value of the timber is basically dependent on its quality. The prices of sawnwood and other forest products fluctuate mainly due to supply and demand. Thus, prices of sawnwood are continuously increasing annually. In this sense, forecasting of sawnwood prices is very important for all stakeholders such as consumer, timber growers, marketers and policy makers. Therefore, this study attempted to analyse the price behaviour of sawnwood in recent past in Sri Lanka with specific objectives, viz. to identify the price behaviour of sawnwood in Sri Lanka and to develop the appropriate price forecasting model for sawnwood. Common timber species (Teak, Jak, Nadun, Mahogany, Burutha, Halmilla Milla, Blue gum, Microcorys, Kumbuk, Sooriyamara, Hora, Coconut and Rubber) were selected for this study. Annual nominal market price of selected timbers was collected from State Timber Cooperation as it is the authoritative government institute to issue the prices of the country. 17 year time duration (1996 to 2013) was considered for analysis. Price behaviour of selected sawnwood was tested by using different time series models viz. linear, quadratic and compound growth rate models. The goodness of fit of model was tested by using coefficients of determination $\left(\mathrm{R}^{2}\right)$.
\end{abstract}

As compared to the 1996 prices, prices of Kumbuk, Teak and Rubber have increased significantly by $531 \%, 431 \%$ and $398 \%$ respectively. Furthermore, price of Microcorys (304\%), Coconut (301\%), Eucalyptus (265\%), Jak (263\%), Hora (257\%), Nedun (247\%), Mahogany (234\%), Burutha (233\%) and Milla (207\%) also increased significantly. However, price of Sooriyamara has increased by $35 \%$ during that time period. Further, annual prices of all types of sawnwood increased continuously as polynomial $\left(y(\right.$ price $\left.)=a+b_{1} x-b_{2} x^{2}+b_{3} x^{3}\right)$ trend ( $\mathrm{x}=\mathrm{year})$. There was no appropriate price forecasting model for Nadun and Halmilla. Except Coconut, Hora, Milla, it was able to develop strong price forecasting models with time for selected timber species. This price forecasting models were in line with the developed price forecasting models for other commodities in Sri Lanka.

Keywords: Sawnwood, Price and polynomial trend 